\title{
Developing the Rural Economy Structure in Agriculture Towards the Betterment of India's Economy
}

\author{
Dhruv Chamaria ${ }^{\mathrm{a}}$, Karan Chothani ${ }^{\mathrm{b}}$, Shivani Darekar ${ }^{\mathrm{c}}$, Viral Darji ${ }^{\mathrm{d}}$, \\ Pinki Vishwakarma ${ }^{\mathrm{e}}$ \\ Computer Engineering Department, Shah \& Anchor Kutchhi Engineering College. \\ Mumbai, India.
}

\begin{abstract}
India is primarily a rural region, with more than half of the country's population and 70 percent of the work force living in rural areas. Approximately 46 percent of national income depends on rural income making it one of the highest contributors of the national economy. Urbanization of inhabitants of rural sector though increasing on an average, it is projected that around 2050 more than half of the national population will be living in rural sectors. Urbanization thus not only affects the economy of the rural sector but, also leaves illiterate farmers back in the village with no manpower and a lot of area. Thus, growth and development of rural economy and population are one of the key factors, to overall growth and comprehensive development of the country. This paper makes an attempt as an assessment in proposing a solution developing a web-based solution for the farmers to find man-power, experts and potential investors for their land. The solution proposed will have different modules to help farmers in every way possible from finding an investor to helping them sell their harvest online to finding man-power their lands.
\end{abstract}

Keywords--Migration, Economy, Rural, Employment Ratio, Agriculture, Technological adaptation, E- commerce Platform, Urbanization.

\section{Introduction}

Urban area is the region surrounding a city. Most people dwelling in urban areas have nonagricultural jobs or jobs that don't require a great amount of physical work. The population of urban area accounts for a total of 34.47 percent of India's population. [1].

Rural areas are also known as the 'countryside' or a 'village' in India. In rural areas, agriculture is the chief source of livelihood with more than 70 percent of working population of rural area directly or indirectly involved with agriculture, and a minimum of 75 percent of male working population involved in agriculture and allied activities [2].Rural population in India was reported at 65.53 percent in spite of which agriculture failed to accounts for majority of India's GDP. This low account of GDP due to agriculture was because, the last decade was marked by an increase in the rate of urbanization by 4 percent with majority of inhabitants of rural area leaving agriculture sector and migrating to metropolitan cities to find work in services, labor and menial jobs which were not being able to live up to the expectation of people that have migrated. Economists and experts say that the labor market will see a tougher challenge over the next period both in the rural areas and in 
urban pockets. This increase in the rate of urbanization increases unemployment rate which in turn decreases the man-power in rural areas and affecting the overall economy.

Agriculture plays an important role in the Indian economy and also proving jobs for half of the India's working class today, however, due to urbanization agriculture contribution to India's GDP has been decreasing over the years, while other service sectors have been gaining its importance. "GDP from Agriculture in India decreased to 4546.58 INR Billion in the second quarter of 2020 from 5306.26 INR Billion in the first quarter of 2020." [3].

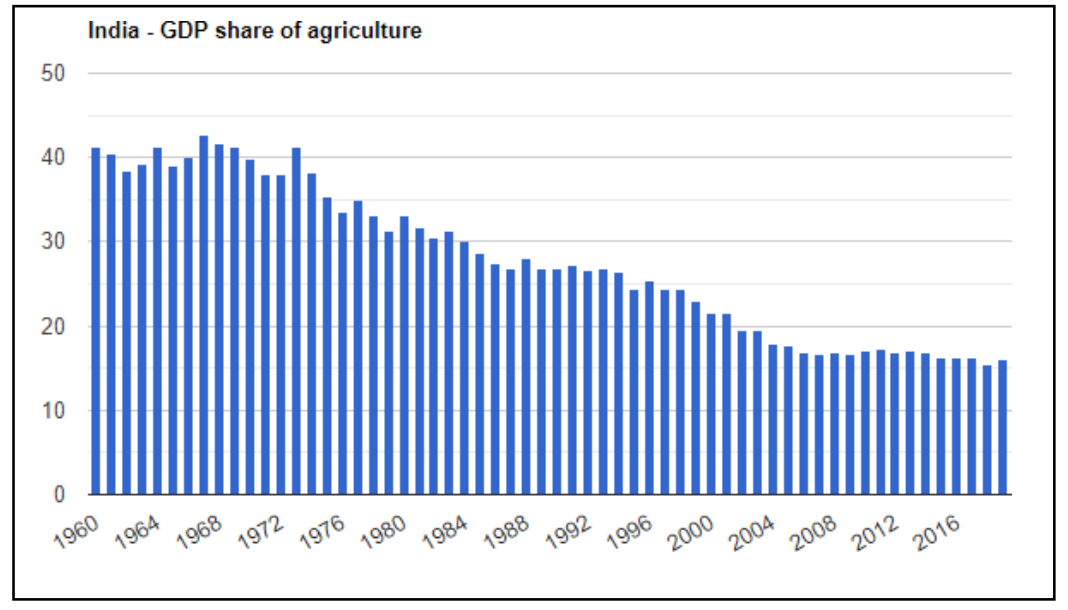

Figure 1. Value added in the agricultural sector as percent of GDP

[17] Data of India's GDP share of agriculture from 1960 to 2019 shows that average value for India during that period was 27.82 percent of at least a minimum of 15.41 percent in 2018 and a maximum of 42.77 percent in 1967. The latest value from 2019 is 15.96 percent. The stats prove that the though agriculture provides employment to more than half of the population of the country the GDP share of agriculture has been constantly decreasing. The reasons for such a drastic decrease are as follows [3].

\section{A. Land}

In countries such as Brazil, Ethiopia, and Australia, land is becoming expensive due to increase in farmers produce and better quality of products. In India, farmland prices are rising not because of their farmers produce but its various other usage. In a country where over half of the population are dependent on agriculture and a third of these live below the average income line, this desperation to exit can only be a silent scream for help. Neglecting it will push India towards greater import dependence and higher food inflation.

Farmers who are doing well are willing to sell, at a significant premium due to having no man-power or youth to help them with new and upcoming farming methods. Most of the farmers are above 60 years, with their sons and sons-in-law settled in the city and unlikely to return. In states such as Andhra and Tamil Nadu villages, all farmers are above 45 years. No one wants their son to be a farmer because it implies, he is good for nothing else creating a negative impact on people looking for taking agriculture as profession. Leasing land to tenant farmers is difficulty is increasing over the period with no willing takers. So, the empty-nesters 
are keen to sell and if they are not able to sell it leaves a lot of good land with no man-power making it barren over the period.

\section{B. Youth Migration}

India has the world's largest youth population, with 354.4 million people aged between 15 and 29 , representing a population share of 27 percent with majority of them being in rural sectors and are willing to migrate or have already migrated. In order to reap the demographic dividend this offers; the education and skills of youth are vital and persuading them to take up agriculture as a profession so that they can maximize their productive contribution [16].

\section{Involvement of Middleman in Farming}

The biggest barrier in increasing farmers income in India are often the racketeering middlemen. Kaccha (small traders), Pakka (larger traders), Commission agents, wholesalers and retailers take a major portion of profit from farmers produce, leaving farmers with very little or nearly negligible. We can see this in many instances over the last decade. For example, take the price of onion which have been fluctuating during this period it nearly reached 120INR per $\mathrm{kg}$ but the farmers were paid the same price of 35INR per $\mathrm{kg}$. The farmers are still on the losing side after several steps have been taking by the government [15].

The farmers are at the hands of the intermediaries who occupy the entire space between the assembly and hence the ultimate selling of the crop, in the absence of an immediate contact with the buyers. This makes middlemen very powerful and therefore the farmers regularly wind up at a snag regardless of being producers. Involvement of middle men are not only during selling of crops but also when any farmer who is willing to sell or lease their land the charge them with a heavy brokerage fess leaving them with less than they should be getting for their land.

\section{Literature Review}

A considerable amount of research has been done on the working and performance of agriculture, migration in search of Jobs etc. in India, by the academicians and researchers. The literature obtained by the investigator, in the form of reports and research studies, is briefly reviewed in this part.

S. Khandare, S. Gawade and V. Turkar stated a project whose objective was safeguard the farmers from natural disasters and their credit eligibility for the next approaching season was listed. The aim of this research is to provide our nation's farmers with an easy to use website and mobile application to support them in order to give all the information regarding government agricultural schemes [11].

R. Marimuthu, M. Alamelu et al. paper discusses about a persuasive technology method (PTM) developed to change the mindset of the farmers towards technology supported farming. The mobile app is linked to the website with details of marketing and farming accessory like dairy, organic products and farm machineries. Based on the requirement, the farmer can learn about the crops, marketing his products and by products or getting support for field operations [12]. 
M. Ayaz, M. Ammad-Uddin et al. paper highlights the potential of wireless nerves and IoT in agriculture, also because the challenges they're expected to face in integrating these technologies with traditional farming practices. IoT devices and communication methods related to wireless sensors encountered in agricultural systems are analyzed well in detail. What sensors are available for a particular agricultural system, such as soil preparation, crop condition, irrigation, insect detection and insecticides are recorded. Finally, based on this thorough review, they tend to identify current and future IoT trends in agriculture and highlight potential research problems [13].

Neupane, R.P., Thapa, G.B studied the influence agroforestry activity on a farm income based on a sample of Dhadhing district subsistence farm families. Benefit research has found that the agricultural system, like agroforestry is more profitable than traditional methods that were previously used. Agroforestry, thus has tremendous capacity to sustainably boost food quality and economic conditions by making meaningful contributions to household income [14].

S. M. Hatture and S. P. Naik within the paper expressed that farmers are typically misled by the middleman, resulting in grain scarcity. An android application in the farmer's native or regional language to assist the unemployed farmers in searching out agricultural jobs relevant to their skill set and obtaining investments from various investors across the nation. In addition to seeking investment for the poor/helpless farmers and creating sufficient agricultural jobs for unemployed farmers so that there is an increase in the progress in the field of agriculture. The intended task of the android application is also to enable farmers with specialized machinery to perform countless agricultural activities, obtain leased land and help purchase and sell agriculture goods using a computerized approach [3].

Bhati and Rakesh presents a study which tries to understand the movement in rural to urban migration, and its results in the form of urbanization. Rural to urban migration can be viewed as a challenge also as it results into the development of the slums, and many other associated problems. It has been observed that rural labour migrates towards urban areas and settled down in slum. The oscillatory growth of urban population has put heavy pressure on public utilities like housing, sanitation, transport, water, electricity, health, and education [7].

Dwivedi, Ritesh's paper discusses how migration is continuing in different parts of India and how it is becoming more and more crucial towards improving livelihood status. Migration of unskilled and skilled labourers has not stopped yet; it is continuing in parts and pieces. Labourers and farmers whose income is not enough that they can have a respected life, they are opting for some other options. India`s top agriculture scientist and one of the architects of India's Green Revolution, Dr. M.S. Swaminathan has warned that the country could face a food crisis if agricultural productivity is not increased and farming is neglected. The future belongs to grains to grains not guns says Dr. Swaminathan. However, the problem of chronic under employment in rural areas is thus essentially due to the event of a failure of seasons and lack of resources. This paper tells us how IOT can be useful for Indian farmers in increasing their income and encouraging agriculture as an occupation. The IoT keen gadget as portrayed and talked about in the paper assumes an essential part in improving farmer life just as builds the harvest creation proficiency. Teaching farmers with visual alarms causes them to settle on better and productive choices. Further, their point is to build up a real usage of the item on a specific horticultural land which would be a genuine contextual investigation for the advancement of their venture [6]. 
Shakeel-Ul-Rehman, M. Selvaraj and M. Syed Ibrahim stated in the paper that Marketing institutions need to optimize the productivity and accountability of producers' transactions and also the retail/consumer price of farmers' transactions. Indian agricultural planners need to pay attention to consumers' demand for agricultural produce. Compared to its current emphasis on development orientation, the agricultural sector should now attempt to achieve a greater business orientation nationally and internationally. [4].

M. S. Farooq, S. Riaz et al. presented a system in which various IoT devices which can be used to help at different stages of agriculture. The main aim of the paper is to minimize human involvement. Lastly, the regulations and policies made by several countries to standardize IoT based agriculture have been presented along with few available success stories. In the end, some open research issues and challenges in IoT agriculture field have been presented [8].

S. Roy, B. J. Sowmya et al. The proposed a system that would help to mitigate the risk involved in agriculture, make it possible to digitize agriculture, cut down on market-based mediators, and thus allow farmers to achieve better agricultural yields and a higher profit margin. The proposed system shall also be of great monetary benefit to the government as they shall be able to deal directly with the farmers in matters of funding and investment in the field of agriculture [9].

S. Shrivastava and S. N. Pal's focus on the Indian context, the proposed architecture for the Next Generation Agricultural Marketing System is to include ICT, Big Data Analytics and Blockchain technologies. The proposed framework majorly comprises of Market Intelligence, Food Supply Chain and One Stop Mobile App as functionalities. It also leverages on government initiatives such as Digi Locker, Aadhaar and Jan Dhan Yojna. The intent is to facilitate farmers to drive Agricultural Marketing System as a co-operative, provide ease of use of available resources to farmers and enable them to take informed decisions [10].

\section{Proposed Methodology}

The situation of youth unemployment continues to be a significant problem, despite an increase in general education rate. As in other countries, youth in India, particularly in urban areas, are far more likely to be unemployed. In recent years, the youth unemployment rate reached a peak of thirteen per cent for young urban men aged 15-19 and eighteen percent for urban women aged 20-24 (Figure 3). In contrast, the rural youth unemployment rate stood at per cent for young women aged 20-24 and 8.9 per cent for young men aged 15-19, respectively. The bulk of unemployed people of urban area belonged to immigrants from rural sectors. The graph below shows that although the weekly wages of people living in rural area has being increase over the years, youth are still migrating to urban areas in search of better jobs opportunity [16]. 


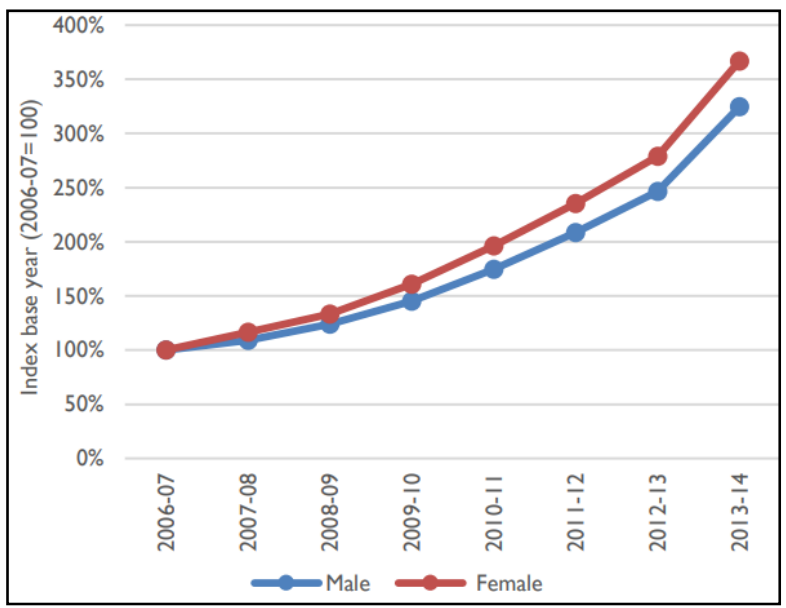

\section{Figure 2. Weekly Wages of Rural Inhabitants}

Further, we found out that majority of farmers that were living in the rural area were over the age of 50 years and the majority of youth had traveled to urban areas in search of jobs. This led to old farmers being incapable/helpless of progressing ahead in agriculture with no manpower and a lot of good uncultivated land [7].

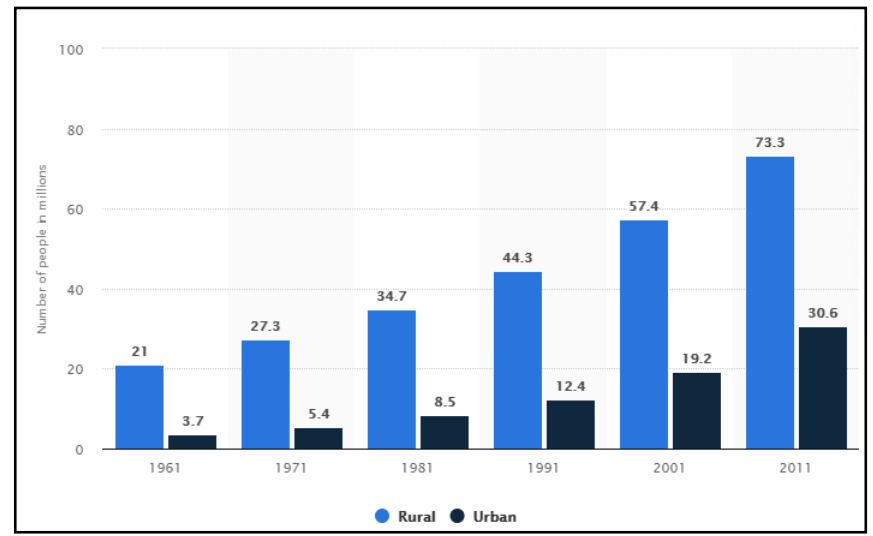

Figure 3. Population of Elderly People in Rural Area

To find problem faced by the farmers, we dived deep into farmers life. Firstly, we researched over internet about the initiative taken by people and other bodies trying to help farmers solve their problems or help them find solution to their problems. As we dug deeper, we came across different Government websites such as www.pmkisan.gov.in, yojana-pmkmy.gov.in, pmfby.gov.in, scheme-soilhealth.dac.gov.in, etc. which educates farmers about risk management, irrigation facilities for their lands. Other bodies want the farmers to work for their own profit on their land also providing loan facilities to farmers. Whereas websites such as 99acres, magic brick offer lands to be sold which reduces the overall income of village and reduces the agricultural productivity since we aim to increase the same. Hence, we carried out a little survey among few farmers where they were asked to try out few farming websites. Now the problem faced by the farmers were-

1. Complex User Interface

2. Poor navigation 
3. Difficulty in understanding

4. Not satisfied with the services provided

A questioner was made for the farmers and investors for the agricultural purpose in order to know their expectations and advisory of the same.

On the basis of our research we proposed a system. Our proposed system will act as a bridge or platform for connecting inhabitants of rural area with the inhabitants of urban areas or vice versa. According to recent study rate of urbanization is increasing on day-to-day basis because inhabitants are _migrating _ to find jobs, and this whole process of urbanization disturbs employment ratio as well as economy of the rural area and also urban area. Therefore, the main aim of our proposed system is to increase the overall economy of the village which will help to increase the overall GDP of India [5].

The proposed system includes a platform for these helpless farmers where they can find manpower, creating job opportunities for the youth (rural as well as urban), connecting land owners and individuals who are interested in buying, selling, renting land for farming purposes, and an e-commerce platform for farmers where they can sell their produce directly without any involvement of middleman. This will help in increasing the economy of the rural area, and also create new employment opportunities for the youth in rural area itself which inturn will also help to abate urbanization. Platform consists of four modules each made specifically to tackle each of the unnoticed problems faced by the famers in recent years.

\section{A. Owners Module}

This the main module of the proposed system. Here the farmers are provided with numerous functionality which will help them to overcome the problems mentioned in previous section of the paper.

Firstly, a "List land" functionality where the farmers who are willing to sell or rent their land for farming purposes to other individuals or farmers. Farmers have to fill details such as location of the land, area of the land, whether they want to sell or rent they land and lastly, they amount they are looking to get for their land. After this procedure their land documents will be verified along with physical verification of location of the land. Once the verification is completed land will be listed in investors module and will be open for potential investors to buy or rent as specified by the farmer.

Second is, "List Job" functionality where farmers who are looking for man-power, or other help such as farming experts or people who can help them with new methods of farming etc. can list jobs in this section of the module. Farmers have to add details regarding the type of post of the job they are providing and number of people they are willing to hire for the same. This job will be visible to people looking for jobs in the rural sector as well the urban sector under job module.

Last is, "Market" functionality where they will add their produce and it will be shown in the e-commerce platform of the proposed system. A quality check will be done on the products they have added, and they will be provided with a certificate of quality is they meet the quality standards. This produce will then be listed under the e-commerce platform where they can view how much they have earned over the period. It will help to remove the middleman and all the profit will be the farmers. 


\section{B. Investors Module}

This module is for investors who are looking to buy or rent land for agriculture purposes. Investors have to verify their documents before having the option to buy/rent land so that farmers are not cheated on. Once the documents are verified, they can view all the lands added buy various farmers across the country and choose to buy/rent any of them. Once they have shown interest in any particular land, contact details of the farmer associated with that particular land will be shared with the investor where further negotiations can take place. Proposed system helps to remove the heavy brokerage farmers have to pay while selling/renting land.

\section{Job Module}

The third module is specially for the youth who migrate to urban areas in a search of jobs and other services. Module cannot only be used by the rural youth, but also for the people living in urban sector of India. Main of this module is to spread awareness regarding agriculture and show to youth that proper techniques and methods in agriculture can fetch you good amount of money.

To prove this, we can see numerous instances of individuals who have accomplished this. Pramod Gautam, a former automobile engineer who switched to farming in 2006, and now gets a yearly turnover of a crore, in the wake of actualizing a fundamentally unique strategy for development. Like Pramod, Sachin is a mechanical engineer from Nagpur who began his vocation by working at a power plant and quickly rose to the top year after year. Sachin left his sumptuous life in Gurgaon, where he was functioning as a manager for Punj Lloyd and getting a robust salary of INR 24 lakh per annum [18]. He moved to Medhpar to become a farmer. Sachin launched his own organization, Innovative AgriLife Solutions Pvt. Ltd., which helped farmers with the contract farming model of farming [19]. Today, Sachin's organization is helping 137 glad farmers working on 200 acres of land and drawing a turnover of roughly INR 2 crore and there are a lot more role models like this two individuals.

When applying for a job the user has to enter his resume or his/her experience in his particular field. They can then view the job available at a different location across the country and apply for the same. Farmers who had posted the job can view this and accept or reject the employee according to his need.

\section{E-commerce Platform}

The second most important module of the system is E-commerce platform. For over a 100 years middleman have been exploiting farmers of money and taking majority of profits that belong to the farmers. Removing this middleman from the chain and delivering quality product to the customers at reasonable prices directly from the farmers produce is aim of this module. Farmers can list the price they are willing to sell their produce. All the profit that comes on the platform will directly be given to the farmer.

A simple dashboard is created from the farmer where he can see the total profit, he has made by selling his produce and can withdraw the money from the platform as and when he requires. For adding more, he can simply go to owner's module and add more produce which after getting certified will be listed under his name on the e-commerce platform. Anyone and everyone can buy on this platform directly from the farmer. Delivery will be fast with minimum charges. 


\section{Discussion}

The proposed system is developed to acknowledge the socio-economic challenges in the agricultural industry. Agricultural methods to increase the farmers produce has been a crucial part in reducing food insecurity across the globe. Agriculture produce has grown over the period which can be seen in the graph below. This growth is majorly due to the increase in commodity prices over the years. As the trade level increases so, will the need for domestic food increase. By 2050, there will have to be enough resources to feed the 9.1 billion estimated population in order to provide food security [8]. Even so, in some developing nations, incentives offered on agricultural production by the governments and very low hence leading to stagnation. And, stagnation affects growth.

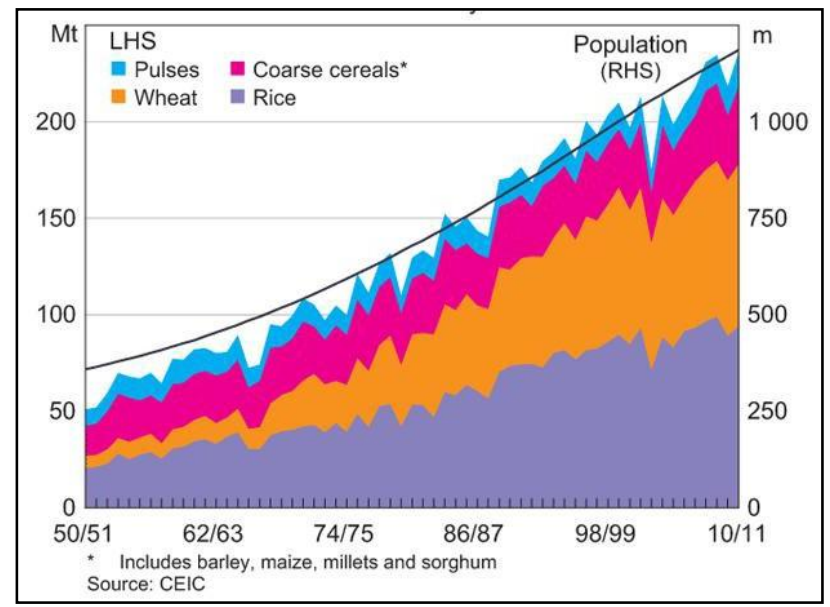

Figure 4. Agriculture Produce From 1950-2011

[20] Farmers are the building block to the agricultural industry. According to a 2011 census, developing nations where agriculture is the main source of income, everyday 2000 young farmers give up farming and the reason being is the income of a farmer is one-fifth of the economy of a non-farmer. Moreover, maximum population involved in farming is above the age of 40. A few years from now, we might not get to see a next generation of farmers. How do we keep the manpower? Generating good revenue for the farmers and providing them with a better life could be one of the ways to motivate the next generation to practice farming [7].

The system is made specifically for the betterment of the farmers to provide them with a lucrative career and transforming farmers as self-sustaining entities. The goal of the system is to help our farmers as in every aspect of farming from getting them manpower to helping unemployed farmers to find jobs, also provide a platform for leasing or selling out their land's without any involvement of middleman and lastly, introducing them to farmer's market so that all profit is distributed among the farmers with an aim of eventually bringing a growth in the economy of the country. To achieve this goal, the system will act as a bridge between potential investors who are very keen in contributing to the agricultural industry, and connect them to authorize needy farmer. The main aim is to provide necessary needs of the helpless farmers. This will lead to the economic growth of the agricultural industry as a whole and social growth of the farmers. With the success of this system, farmers will also have a fixed profit margin and a better market reach.

\section{Conclusion}

With an increase in digital India, applications and new innovative ideas are the way to move forward with a goal of increasing economy of India. Agricultural sector is one of the most important areas of concern over the last decade and has seen the least development or innovation in technology. 
Proposed framework can be used along with various other technologies in this advancing world. This proposed framework is created keeping in mind they need of farmers in modern era. Its fundamental idea is to make farmers independent and self-sufficient. Various modules are created to handle explicit issues of the farmer otherwise unnoticed. Owner's Module helps the farmers to connect with outside world and present their requirements. Investors module for people keen on leasing out land or buying one (only for farming purposes) without any involvement of middleman. Job module to help the skilled jobless farmers of the villages to find job in their hometown. Lastly, the e-commerce platform where farmers can sell directly without any middleman taking up their profits.

Our preliminary results will guide further research in the field of agriculture. New ideas and technology will be introduced and collaboration with third-parties to further enhance the growth of agriculture in India which in turn will help to increase overall economy of the nation.

\section{REFERENCES}

1. Ramalatha Marimuthu, Alamelu. M, Suresh. A, Kanagaraj. S "Design and Development of a Persuasive Technology Method to encourage Smart Farming”, 2017 IEEE Region 10 Humanitarian Technology Conference (R10-HTC) 21 - 23 Dec 2017, Dhaka, Bangladesh.

2. Samruddhi Kandare, Sushopti Gawde, Varsha Turkar "Design and Development of E-Farm with SCHEME", Proceeding International conference on Recent Innovations is Signal Processing and Embedded Systems (RISC-2017)27-29October,2017.

3. S. M. Hatture and S. P. Naik, "Agro-Guardian: A Framework for Smart Agriculture," (2019) 1st International Conference on Advances in Information Technology (ICAIT), Chikmagalur, India, 2019, pp. 109-115.

4. Shakeel-Ul-Rehman, M. Selvaraj and M. Syed Ibrahim (2012): "Indian Agricultural Marketing- A Review", Asian Journal of Agriculture and Rural Development, Vol. 2, No.1, pp. 69-75.

5. Harpreet Singh (2016): "Increasing rural to urban migration in India: A challenge or an opportunity", International Journal of Applied Research.

6. Dwivedi, Ritesh. (2012): "Migration: An Overview and Relevant Issues", Management Insight, Vol. 8, pp 24-32.

7. Bhati, Rakesh. (2015): “A study of Rural to Urban Migration in India”, ASM's International E-Journal on Ongoing Research in Management and IT.

8. M. S. Farooq, S. Riaz, A. Abid, K. Abid and M. A. Naeem, "A Survey on the Role of IoT in Agriculture for the Implementation of Smart Farming," in IEEE Access, vol. 7, pp. 156237-156271, 2019.

9. S. Roy, B. J. Sowmya, S. Seema, S. Rajeshwari and M. S. Vinutha, "Utility System for Elevating Pre and Post Production of Crops," 2019 IEEE International Conference on Distributed Computing, VLSI, Electrical Circuits and Robotics (DISCOVER), Manipal, India, 2019, pp. 1-6.

10. S. Shrivastava and S. N. Pal, "A Framework for Next Generation Agricultural Marketing System in Indian Context," 2019 IEEE International WIE Conference on Electrical and Computer Engineering (WIECON-ECE), Bangalore, India, 2019, pp. $1-4$. 
11. S. Khandare, S. Gawade and V. Turkar, "Design and development of e-farm with S.C.H.E.M.E., "2017 International Conference on Recent Innovations in Signal processing and Embedded Systems (RISE), Bhopal, 2017, pp. 593-600.

12. R. Marimuthu, M. Alamelu, A. Suresh and S. Kanagaraj, "Design and development of a persuasive technology method to encourage smart farming," 2017 IEEE Region 10 Humanitarian Technology Conference (R10-HTC), Dhaka, 2017, pp. 165-169.

13. M. Ayaz, M. Ammad-Uddin, Z. Sharif, A. Mansour and E. M. Aggoune, "Internet-ofThings (IoT)- Based Smart Agriculture: Toward Making the Fields Talk, "in IEEE Access, vol. 7, pp. 129551-129583

14. Neupane, R.P., Thapa, G.B. RETRACTED ARTICLE: Impact of agroforestry intervention on farm income under the subsistence farming system of the middle hills, Nepal. Agroforestry Systems 53,31- 37 (2001).

15. Sumbul Mashhadi, "Farmers, Middlemen and the Way Out", February 5, 2019, available at: [ https://spontaneousorder.in/farmers-middlemen-andthe-way-out/].

16. Government of India. Ministry of Housing and Urban affairs Government of India, "HANDBOOK. OF. URBAN STATISTICS. 2019.", 1 March 2019, available at: [http://mohua.gov.in/pdf/5c80e2225a124Handbook\%20of\%20Urban\%20Statistics\% 202019].

17. The world bank, available at: [ https://www.theglobaleconomy.com/India/Share_of_agriculture/].

18. Manabi Katoch, "5 Farmers Who Prove Smart Agriculture Can Make You Rich", available at: [http://www.developmentnews.in/5-farmers-prove-smart-agriculturecan-make-rich/]

19. Manabi Katoch, "As an Engineer He Earned Rs 24 Lakh. As A Farmer He Earns Rs 2 Crore!', April 4, 2017 available at: [https://www.thebetterindia.com/94285/sachinkale-innovative-agrilife-solutions- engineer-turned-farmer/].

20. Adam Cagliarini and Anthony Rush, "Economic Development and Agriculture in India", June 2011, available at: [ https://www.rba.gov.au/publications/bulletin/2011/jun/3.html\#fn0]. 